Penultimate version. If citing please refer instead to the published version in Human Resource Management Journal, 23(12), 2013

\title{
Homeworking: Negotiating the psychological contract
}

This paper explores the psychological contract of female clerical homeworkers who work from home full-time and are employed at a Local Authority. Qualitative interviews were carried out with homeworkers and their supervisors. Temporal flexibility was desired by all the homeworkers in order to achieve a better work-life balance and was deemed important by women without children as well as those with childcare responsibilities. Our findings highlight that homeworkers were able to negotiate their own idiosyncratic deals with line managers in order to attain their desired levels of temporal flexibility. However, the issue of flexibility remains ambiguous with some supervisory staff being more comfortable with the concept than others leading to some homeworkers enjoying different levels of temporal flexibility than their co-workers. Our findings suggest that employees perceive flexibility idiosyncratic deals of co-workers as fair as long as they achieve their own personal levels of temporal flexibility. The potential implications for organizations are discussed.

Keywords: Idiosyncratic deals, Psychological contract, homeworking, work-life balance, temporal flexibility

\section{Introduction}

This paper draws upon the psychological contract as an explanatory framework to explore the employment relationship of homeworkers. Although flexible working arrangements such as homeworking are increasingly being utilised by both public and private organizations little is 
Penultimate version. If citing please refer instead to the published version in Human Resource Management Journal, 23(12), 2013

known about how working from home impacts upon the employment relationships; what employees expect from the organization when working from home or how the move to homeworking is negotiated. Negotiation is a particularly important area because line manager support for organizational flexible working arrangements influences their implementation and practice across departmental areas (McCarthy et al., 2010).

The psychological contract concerns reciprocal obligations (and hence expectations) between employer and employee (Rousseau, 1989) and was utilised as an explanatory framework because it has become a pivotal focus in the study of employee relations (Guest and Conway, 2002). Most studies into the psychological contract have addressed the issue of contract breaches or violations and only about ten per cent of contemporary studies have used qualitative methods (Conway and Briner, 2005; Coyle-Shapiro and Parzefall, 2008). The psychological contract can be seen as a highly subjective concept involving different individualised interpretations (e.g. Rousseau, 1995). Using qualitative methods, such as the in-depth interviews utilised in this study, are essential for developing our understanding of these subjective and idiosyncratic contracts because the data are 'grounded in the language of employees and organizational context’ (Conway and Briner, 2005:97)

We explored the content of the psychological contract of homeworkers to determine what they expect from the employer-employee relationship. Previous research has investigated the psychological contract for specific types of employees such as nurses (Purvis and Cropley, 2003), ethnic minority employees (Chrobot-Mason, 2001), expatriate managers (Guzzo et al., 1994) male and female managers (Scandura and Lankau, 1997) as well as homeworking clerical staff (Tietzeand Nadin, 2011), a similar cohort to this study. In general, employees expect the provision of a safe and pleasant working environment, high pay, pay based on current performance levels, promotion and advancement, job security, fairness and 
Penultimate version. If citing please refer instead to the published version in Human Resource Management Journal, 23(12), 2013

responsibility from their employer (e.g. Robinson, Kratz and Rousseau, 1994; Herriot, Manning and Kidd, 1997; Robinson and Morrison 1995; Purvis and Cropley, 2003). Such studies suggest that at the heart of the psychological contract are key themes that are important to the majority of workers. However, Purvis and Cropley (2003) found themes that were specific to nurses as a professional group e.g. safety. Given that an identified disadvantage of homeworking is fewer promotion prospects (Olson and Primps, 1984; Baruch, 2001) it suggests that this aspect of the psychological contract is not important to homeworkers if they are willing to give it up. However, as homeworking was adopted by the organization as part of their work-life balance initiative it is likely that flexibility will be an important feature of the psychological contract.

Idiosyncratic deals in relation to work-life balance initiatives are discussed in the following section, followed by a section on work-life balance. The case study approach adopted in this study is then described along with the findings from the qualitative interview data. The implications of the research are then considered with respect to both theory and organizational practice.

\section{Idiosyncratic deals}

Idiosyncratic (I-deals) are one way in which researchers can explore how the psychological contract can be managed by individual workers (Conway and Briner, 2005). I-deals are the negotiated terms of employment that an individual employee receives which differ from those that co-workers in comparable roles receive (Rousseau, 2001, 2005). They are voluntary, flexible, personalised and usually informal, implicit arrangements which benefit both employer and employee (Rousseau, 2005; Guest, 2004). Whereas formal transactional deals are likely to be made whilst joining the organization for example with senior managers or the 
Penultimate version. If citing please refer instead to the published version in Human Resource Management Journal, 23(12), 2013

human resource function, i-deals are likely to be negotiated with immediate superiors (Guest, 2004; Hornung et al., 2008, 2009) rather than more senior executives (Anand et al., 2010).

Increasingly, organizations are incorporating work-life-balance initiatives as part of their human resource policy. The 2000 Work-life Balance Survey found that homeworking and flexible working arrangements such as flexitime and term time contracts were not widely available although $47 \%$ of employees who did not have flexitime desired it (Hogarth et al., 2000). By 2007 the third work-life balance survey found flexible working was available to 53 per cent of employees, a compressed working week (fulltime hours over fewer days) was available to 35 per cent of workers and working from home was available to 23 percent (Hooker et al., 2007).

Flexibility of work hours has been identified as a prevalent form of I-deal (Rousseau, 2005; Hornung, Rousseau, Glaser, 2008, 2009). Flexible contracts may be one way in which organizations try to attract and retain high quality individuals. One worker’s flexible working i-deal may negatively impact on colleagues (Lai, Rousseau and Chang, 2009), can lead to resentment (Rousseau, 2005) and perceived to be unfair (Greenberg et al., 2004). However, colleagues are more likely to accept the i-deals of others and view them as fair if they involve personal friends (Lai, Rousseau and Chang, 2009) or they believe they can make similar deals themselves (Rousseau, Ho and Greenberg, 2006).

Temporal flexibility is important to individuals and features prominently in i-deals of employees. As Hornung Rousseau and Glaser (2009:742) point out 'I-deals are negotiated in the context of the overall employment relationship'. Thus, in exploring what is important in the psychological contracts of homeworkers we found that respondents had attained differing levels of flexibility we therefore also draw upon Rousseau's (2001, 2005) work on I-deals to explore the levels of temporal flexibility negotiated on an individual basis by clerical staff. 
Penultimate version. If citing please refer instead to the published version in Human Resource Management Journal, 23(12), 2013

\section{Work-Life Balance}

Increasingly organizations are introducing initiatives that allow employees manage their work and non-work domains. Typically such initiatives include part-time working, flexi-time (employees can vary start and finish times), term-time working (employee only works during the school term) and home working (employee works at home for all or part of the week). In the UK twenty-two percent of requests for flexible working have been made by women compared with 14 per cent of men (Hooker et al, 2007). Overall for 43 per cent of women and 22 per cent of men, childcare was given as the reason for requesting flexible working (Holt and Grainger, 2005). Felstead et al., (2002) found that three-quarters of those working mainly at home are women, although men are more likely than women to have the option (60.7\% and 39.3\% respectively). The idea of an enhanced work-life balance for everyone, not just parents with child care commitments, has been discussed in the media (e.g. Keating, 2006; Higginbottom, 2006) and is of interest to academics and practitioners (e.g. Fagan et al., 2006, Tom, 2004). Nadeem and Henry (2003) found that both men and women would like greater flexibility in their working arrangements.

Research has identified two main work-life balance reasons for employees to work at home: the ability to manage work and family commitments (e.g. Huws et al., 1990; Haddon and Silverstone, 1993; Tietze and Nadin, 2011) and increased flexibility of working hours (e.g. Felstead and Jewson, 2000). Increased autonomy in how time is organised can allow some workers to 'snatch moments' of time and use them for their own personal use which has the potential to enable flexible or home based workers to lead richer lives (Tietze and Musson, 2005:1342). However, although homeworking can improve work-life balance it can also maintain traditional gendered roles within the home with women using their increased flexibility to do housework or care for dependents (Crossan and Burton, 1993; Sullivan and 
Penultimate version. If citing please refer instead to the published version in Human Resource Management Journal, 23(12), 2013

Lewis, 2001; Hilbrecht et al 2008) whilst men are more likely to use flexibility to work longer hours (Sullivan and Lewis, 2001).

Drew and Murtagh (2005) suggest that senior managers are concerned that expanding the availability of flexible working arrangements will increase the pressure on employees who do not work flexibly and cause resentment. However, Hogarth (2001) found that the majority of employees were not concerned about the potential unfairness of such policies. Increasingly people are prepared to take cuts in remuneration in order to have greater job satisfaction and quality of life (e.g. Avaya, 2009; Nadeem and Hendry, 2005; Higginbottom, 2006). A survey by PricewaterhouseCoopers (2010) of 1,167 UK professionals revealed that $47 \%$ (41\% of men and $54 \%$ of women) value flexible working above bonuses. Thus, however temporal flexibility is utilised the research suggests that it is important to employees and is likely to be part of the psychological contract of homeworkers.

The overall research incorporated organizational expectations of staff from the perspective of managers and supervisory staff. However, the aim of this article is to explore the content of the psychological contract of homeworkers, although some of the input of the supervisory staff has been retained to add depth and context to the narrative of the homeworkers. The following two key research questions have been identified to pursue this aim:

- What expectations homeworkers have of the employing organization

- What expectations homeworkers have of the homeworking scheme

\section{Study Methodology and sample}

The research was carried out in an English local authority. Following a pilot scheme, homeworking was offered across the authority as part of a wider strategy, including 
Penultimate version. If citing please refer instead to the published version in Human Resource Management Journal, 23(12), 2013

compressed and flexible working, to improve working conditions and service delivery. The homeworking scheme was voluntary and employees who worked from home full-time were all clerical staff.

This research adopted a case study approach which focussed on one organization to allow the organizational context of the participants accounts to be explored. In order to investigate the psychological contract of homeworkers we felt it was important to access the interpretations, experiences and perceptions of each participant. In this respect qualitative semi-structured interviews were seen as appropriate because the focus of this study was 'on the meaning of particular phenomena to the participants’ King (1994a:16) and so were used to gain an understanding of the participants' world. Thus the data collected are based upon the narratives of homeworking clerical staff in which they describe and explain the expectations they have of their organization.

Fieldwork took place in the summer of 2004. Thirteen homeworkers participated in the research out of a possible twenty-two employed by the organization in this capacity; eleven of which were full-time and two part-time. In addition two managers, six supervisory staff (including one who was a homeworker) and twelve office based employees also took part in the study. All homeworkers were female clerical workers who worked from home on a permanent basis. The majority of the homeworkers interviewed either accepted a demotion or gave up a promotion to remain a clerical processor in order to work from home. The next promotional level involved answering telephone enquiries from the public which homeworkers were unable to do because the technology was not available. They did not go into the office to work except on exceptional occasions such as training. Overtime was rare and the homeworkers tended to work their assigned hours. The time the participants had worked from home ranged from 10 months to four years. Team leaders can monitor staff in a 
Penultimate version. If citing please refer instead to the published version in Human Resource Management Journal, 23(12), 2013

number of ways: phoning the homeworker; checking the amount of letters that the homeworker prints out at the office (these are then sent out by office staff); monitoring the number of claims processed; and checking whether they are logged on to the system. Visiting homeworkers 'on spec' was not carried out to monitor staff, team leaders would always make an appointment with the homeworker before visiting them.

Three sections took part in the study: council tax and benefits in which homeworkers process and assess claims; and service development in which the homeworker provided administration support to managers. Interviews with staff from council tax services were arranged by the section manager. The contact details of nine homeworkers were given to the researcher by the manager of the benefit section, six of which were contacted directly by the researcher via telephone and all agreed to take part in the study.

All the participants were interviewed by the first author on an individual basis at their usual place of work. Interviews lasted between 20minutes and one hour. All participants consented to the interviews being taped and all were transcribed verbatim. The semi-structured interviews covered three key areas: What the employee expected from the organization, whether these expectations were met and what the employee believed the organization expected of them in return. An interview schedule was used but interviewees were encouraged to use their own words to relate their personal experiences and interpretations of the psychological contract. Issues and areas raised by the respondents were also encouraged. Consistent with the epistemological stance adopted in this study, the narratives of the respondents were viewed as socially constructed in that we have assumed that individuals actively construct their social world, they interpret events, contexts and situation and act as a consequence of their interpretation. Table 1 shows the details of the participants (identified by pseudonyms). 
Penultimate version. If citing please refer instead to the published version in Human Resource

Management Journal, 23(12), 2013

- put table one here -

Template analysis was used to organise and analyse the data (King, 2004b). This is a process whereby textual data is categorised and coded according to identified themes. The initial template was developed using a priori codes generated from the research questions, which is common practice. The codes were then revised and refined as the template was modified. The initial template was used to work through the transcripts and identify relevant themes from the text which were then coded. Template development was an iterative process as the template is revised as the analysis progresses with subsequent transcripts. The final version of the template was then applied to all the transcripts. A number of key themes were identified: why the homeworkers decided to work at home; the expectations of homeworking and office based employees in terms of the organization and of each other; organization expectations of the employees (from the perspective of managers and supervisory staff); who represents the organization in terms of fulfilling employee expectations; Issues surrounding trust; and an exploration of the consequences to both the organization and employees when expectations are not met. For this paper we have focussed on the expectations that homeworkers have of their organization and represents a small part of the overall research.

\section{Findings}

This study investigated the content of homeworkers' psychological contracts by exploring their perceived expectations of the organization. For all thirteen homeworkers the team leader, or immediate manager, was perceived as being responsible for fulfilling their expectations with regards their psychological contract. The interviews with team leaders and 
Penultimate version. If citing please refer instead to the published version in Human Resource Management Journal, 23(12), 2013

immediate managers are included in this section in order to get their perspective of organizational expectations of the homeworkers. The participants were asked what they expected from the organization apart from pay. The expectations of the homeworkers with respect to the organization revolved around six themes which are summarised in table 2 . The focus of this paper is on the two key themes of temporal flexibility and fairness.

- put table two here -

\section{Temporal Flexibility}

The terms and conditions of employment for homeworkers were the same as for office-based staff, although the organization had implemented a specific homeworking agreement. The agreement did not promise flexibility of working hours, although it did state that any variation to working hours must be agreed with the line manager. However, temporal flexibility was expected of the organization and in general the homeworkers felt that this expectation had been met by the organization. The importance of temporal flexibility is underlined when the factors influencing homeworkers' decision to work at home are examined; nine homeworkers cited flexibility of hours and thirteen homeworkers cited the ability to balance work and family life as the two main factors influencing their decision to work at home.

Six staff without children, or dependent children, appreciated the greater temporal flexibility associated with homeworking that enabled them to balance their work and family life. Homeworkers with children stressed the advantages of being able to be flexible in times of illness, school holidays and taking children to and from school while still working on a 
Penultimate version. If citing please refer instead to the published version in Human Resource Management Journal, 23(12), 2013

fulltime basis: 'basically the quality of my life was just horrendous and I thought it would improve it for me and my family’ (Louise)

As one homeworker without children stated she had nothing 'against work' but felt that work should be of benefit to her: 'I just think I'm a bit selfish...it's like it's got to benefit me' (Gillian). One homeworker was doing an Open University course and work her hours around completion of essays for the course. Another homeworker was able to arrange her working hours so 'I can do all my housework on Friday,' homeworking also means that work 'can sort of fit round my life rather than me fitting round work’ (Katherine) which echoes Gillian’s comments of work being of benefit. Thus the ability to achieve a better work-life balance was important to homeworkers without dependent children as well as those homeworkers with childcare responsibilities. This idea of employees wanting to fit work around their life is echoed in the media which has given a great deal of attention to the benefits of achieving a work-life-balance. One homeworker who has a child at secondary school effectively sums this up:

I’ve always worked full-time right from leaving school at 16 and the only time off was at the weekend when I was also somebody's mum and I had to organise them as well'. However, by working condensed hours: 'I get every Wednesday off and it’s my day really to do what I want to do. (Amanda).

The availability of the organization's computer system meant that, in principal, homeworkers could work their allotted hours any time between 7am and 7pm. However, what emerged from the data was that the level of temporal flexibility enjoyed by homeworkers within both the council and benefitssections appeared to be dependent upon the discretion of the team leaders rather than organizational policy. For example, one team leader, Jennifer, was responsible for several homeworkers including Laura, Amy, Katherine, and in theory, Sophie, 
Penultimate version. If citing please refer instead to the published version in Human Resource Management Journal, 23(12), 2013

who all enjoyed varying levels of flexibility. Sophie, who had worked for the organisation for a number of years, would not approach Jennifer unless she could avoid it but preferred to go to Guy, Sam or Mathew or even bypassing the team leaders altogether by going straight to the manager:

Because you're supposed to go to the team leaders and they're rubbish and so I go direct to him (Sophie).

Whilst Laura did accept Jennifer as her team leader she maintains that she enjoys a great deal of temporal flexibility as when she first went homeworking two years ago the organization said 'yes, you can do your 37 hours anytime of the day that you want to do it', thus when she goes to the dentist or to the shops she does not inform her team leader as 'they know if your mobile is switched off you're not working' (Laura). In contrast two other homeworkers, Amy and Katherine, who have been working at home for less than a year talked of having to do core hours that are between $9.30 \mathrm{am}$ to $4 \mathrm{pm}$ so 'we've still got flexibility but not sort of too much' (Amy). Although Katherine did negotiate some flexibility with the team leader, Jennifer, in terms of working longer hours on a Monday and shorter hours on a Friday, the arrangement was a permanent feature of the working week and not allowed on an ad hoc basis.

This idea of core hours seemed to come from Jennifer the team leader rather than the section manager who stated that the section tried to be as flexible as possible within the constraints of the computer system although he did expect homeworkers to inform the office if they want to take time off:

You know they haven’t got carte blanche as regarding...they want to go shopping for 2 hours or things like that... as long as we know that they are not processing 
Penultimate version. If citing please refer instead to the published version in Human Resource Management Journal, 23(12), 2013

and they have signed themselves off and the time sheets filled in (Peter, Manager).

Both Amy and Katherine stated that they have to work a surplus of hours prior to taking time off. In contrast Sophie is able to take time off and make it up later in the week, as long as the time deficit is seen to be decreasing: 'so I just make up an hour a week...they don’t bother as long as they can see it going down...so they don’t impose time limits on you’ (Sophie).

Sophie and Laura, who have been homeworking for two and four years respectively, negotiated their flexibility with another team leader. Jennifer, a new team leader, had accepted flexible arrangements previously negotiated but appeared to allow less flexibility in her own negotiations with more recent homeworkers such as Amy and Katherine. This suggests that expectations of flexibility are formed by theteam leader and the homeworker during the initial process of arranging for the employee to work at home.

Another team leader also appeared to allow less flexibility and his staff generally worked set days:

I still sort of say to [Richard, team leader] what days I'm working and what hours roughly that I'm doing...it's not a case of ...I'll just decide to clock off for three hours and come back it's not as easy as that (Charlotte).

Interestingly Charlotte appreciated her team leader allowing her the flexibility he did, especially in relation to other team leaders in the office:

I don't think they liked the flexibility...I don't think they liked the idea of homeworking at all and they still wanted to keep it very fixed and very rigid and that wasn't really the intention of what homeworking was (Charlotte). 
Penultimate version. If citing please refer instead to the published version in Human Resource Management Journal, 23(12), 2013

In contrast within the same section another team leader allows greater flexibility and permits their staff to work their hours any time between $7 \mathrm{am}$ and $7 \mathrm{pm}$ :

They don’t mind when you work as long as you do your correct number of hours, so if you want to take a big three hour gap in the middle of the day......you can do that. (Gail).

Gail stated that she informs her team leader, Debbie 'out of courtesy' and Debbie confirmed that homeworkers could work their contracted hours any time during the day however she did expect to be informed of any change. Thus, some of the supervisory staff did appear to dislike the idea of flexible working perhaps because it made supervising the homeworkers more difficult. As one of the managers points out:

I think this is where some managers struggle with homeworking as well because again they can't see the flexibility thing...it's like if they're not working when they should be working then they can't possibly be doing any work (Rebecca, Manager).

Thus, temporal flexibility was very important to the participants and they expected it from the organization. In general, the participants felt that their expectation regarding temporal flexibility had been met because they had been able to negotiate different levels of flexibility to suit their personal work-life balance.

\section{Fairness}

Fairness was important to the homeworkers. All of the homeworkers stated that they expected fairness from the organization and overall it was felt that the organization had met this expectation: 
Penultimate version. If citing please refer instead to the published version in Human Resource Management Journal, 23(12), 2013

You know they're good to work for...they're very fair...I've never had any problems as such. If I've needed time off at short notice...they will try and accommodate everything (Gail).

I expect them to be fair, which on the whole they generally are (Sophie).

What emerged from the data was that homeworkers expected to: 'be treated the same as any other [processor] really’ (Helen). Issues of fairness tended to revolve around the organization applying the same pay, benefits, rules and procedures to all clerical staff. Thus, homeworkers expected the same pay rises and benefits as their office based colleagues which they did receive. Interestingly, the office based staff did not raise the issue of greater flexibility being allowed to the homeworkers.

One of the homeworker's stated that the variety of work had increased, as had the work load, since they started to work from home but were not paid more:

I mean it was our choice...we did say I would like to learn something else but we just seem to be ...I'm getting more and more and now I don't honestly feel that we're paid [enough] (Louise).

However, two other homeworkers stated that they enjoyed the variety of work as 'we used to get all the jobs that took a long time' but this had changed as the Authority had 'heard people’s grievances' and 'now it is getting better' (Laura).

If a homeworker was taken back into the office because they were not working their hours, two of the homeworkers said they expected that person to be dealt with and not all the homeworkers: 
Penultimate version. If citing please refer instead to the published version in Human Resource Management Journal, 23(12), 2013

Well that would be the fairness but it's...that's what you would expect the Council to do...deal with that one issue and not deal with us all as a whole (Sophie).

Fairness appeared to be a two way process in that if the employees perceive the organization to be fair they feel more committed to reciprocate, as one homeworker said:

Well...if they're fair with me...I try and put in my commitment with them erm...they're expecting me to be honest and reliable and putting the hours in I'm supposed to be doing...therefore I think it's only...in fairness for me to do that (Hannah).

Thus fairness is an important part of the psychological contract. Another homeworker perceived fairness to be an important part of loyalty stating that if she had the chance of moving to another organization that offered homeworking:

That would have to take some thinking about because the council have invested a lot of money in me and this is where the loyalty comes in isn't it? You've got to be fair (Sophie).

However if the organization terminated the scheme 'that would be a different matter' and she would move to another organization, preferably one with a homeworking scheme (Sophie). Thus, fairness was a key expectation of the homeworkers and in general it was felt that the organization had met this expectation, despite variations in the flexibility allowed to homeworking staff.

\section{Discussion}


Penultimate version. If citing please refer instead to the published version in Human Resource Management Journal, 23(12), 2013

The findings from this research revealed two key themes, temporal flexibility and fairness that were important to homeworkers. The majority of homeworkers in this study either accepted a demotion or gave up a promotion in order to work from home which suggests that greater flexibility and attaining the desired work-life balance is more important than career, supporting other research (Tietze and Nadin, 2011). The majority of homeworkers, with and without children, used temporal flexibility in order to carry out domestic work at home, in line with traditional gendered roles (Tremblay, 2002; Sullivan and Lewis, 2001; Tietze and Nadin, 2011) and did not question whether having the main responsibility for household chores or care giving whilst working full time was fair (Hilbrecht et al, 2008). However, some homeworkers were still able to utilise flexible working for personal leisure, for example, pursing an Open University degree which suggests that temporal flexibility is not used solely for domestic reasons.

The data highlights the importance of flexibility within the psychological contract of homeworkers. As Hornung (2008:658) has pointed out organizational schemes, which allow employees to work at home, ‘signals flexibility’s legitimacy’ and theirintroduction provide an opportunity for new routines to be developed. Although flexibility was not discussed in the homeworking policy; it states that any variation of hours must be agreed with the manager. However, the accounts of both homeworkers and the supervisory staff include reference to flexibility. Thus, individual homeworkers have developed idiosyncratic deals for themselves in order to attain their desired levels of flexibility.

Our findings found that such differences in temporal flexibility appear to be a result of who they negotiated with. Supervisors had developed different interpretations and perspectives regarding flexibility and therefore differed in their implementation of flexibility. For the homeworkers in this study their team leader or immediate manager represented the 
Penultimate version. If citing please refer instead to the published version in Human Resource Management Journal, 23(12), 2013

organization in terms of their psychological contract which supports other research (e.g. Conway and Briner, 2002; Tekleab and Taylor, 2003). Thus, the team leaders have a great deal of control over the homeworkers working conditions, including flexibility and hold greater power in any negotiation than the homeworker. This supports research by Nadeem and Hendry (2005) who found that the implementation of flexible working was restricted by managers despite the organization having formal policies and guidelines. Making line managers responsible for HR related issues can result in inconsistencies in how policies are applied (McCarthy et al., 2010). As one manager in the current study pointed out some of the team leaders struggle with the concept of flexibility and if homeworkers take time out during the 'normal' 9 to 5 working day managers may wonder whether they are doing any work at all. Thus, the issue of flexibility remains highly ambiguous, as another manager maintained they try to be flexible but the homeworker has not got 'carte blanche' to take two hours off without informing the organization. This is an interesting issue and raises the question what is the risk to the organization? The organization can obviously monitor the homeworkers at any time. Any cases where staff are not working their scheduled hours can be determined, so why not allow staff the flexibility to work between $7 \mathrm{am}$ and $7 \mathrm{pm}$ which is what the computer system allows?

Flexibility can result in new challenges as both parties try to negotiate a working relationship which acknowledges and meets the needs of both the organization and the employee (Johnson 2004). Some supervisory staff may find it hard to 'let go' of the control which the traditional working patterns fostered. At one level this reluctance could be due to the fact that traditionally work and home have been segregated (Tietze and Musson, 2002). However, homeworking results in a blurring of these two boundaries which will have an impact on homeworkers and those who manage them. An important point is that when visiting employees at home, supervisory staff have become guests of their subordinates (Felstead et 
Penultimate version. If citing please refer instead to the published version in Human Resource Management Journal, 23(12), 2013

al., 2003). Previous research has found that both managers and subordinates 'reported experiencing ambiguities and uncertainties of power, authority and status in their interactions' (Felstead et al., 2003, p.250). It may be that controlling the flexibility of homeworkers is one way in which supervisory staff can emphasise their authority and power.

Alternatively supervisors may be reluctant to allow homeworkers greater flexibility because of ontological security which refers to a stable 'mental state derived from a sense of continuity and order in events' (Bilton et al., 1996:665). Supervisors may be more comfortable adhering to work patterns established prior to the introduction of homeworking. In developing a homeworking policy, it could be argued that the organization has attempted to establish an unambiguous standard for managers and teamleaders to implement (Feldman and Pentland, 2003). However, the organizational routine of managing homeworkers is ultimately performed by individuals who will bring their own interpretation, goals and understanding to the situation. Thus, 'there is no single, objective routine, but a variety of different perspectives on what is involved' (Feldman and Pentland, 2003 p.104).

Organizational routines adapt over time (Feldman and Pentland, 2003; Dick, 2006) as aspects of routines are varied, selected and retained by the actions of the individuals involved. Likewise the findings from this study suggest that team leaders have brought their different perspectives and interpretations to the issue of flexibility, have contested and thereby varied the level of flexibility and in doing so have shaped the negotiation between the organization and the homeworker. The supervisors' opinion of an individual formed through face-to-face contact in the office may form the basis of the relationship when homeworking. If a supervisor has some doubts as to whether a homeworker can be trusted they may try to control their levels of flexibility to a greater extent than those of a homeworker they deem to be trustworthy. 
Penultimate version. If citing please refer instead to the published version in Human Resource Management Journal, 23(12), 2013

Fairness was important to the homeworkers and is a key issue in the negotiation of the psychological contract (e.g. Guest, 1998; Herriot and Pemberton, 1995). This is an interesting finding given that homeworkers enjoy differing levels of flexibility and those that did receive less flexibility than their colleagues were still appreciative of the level they were allowed. Intuitively, allowing homeworkers different levels of flexibility is likely to result in homeworkers allowed less than others questioning the fairness of the organization especially as individuals tend to make comparisons against co-workers who are at their own employment level (Rousseau, 2005; Lei, Rousseau and Chang, 2009). However, our findings suggest that differing levels of flexibility allowed are not viewed unfairly because individual homeworkers had been able to negotiate their working times to suit them personally and were happy with their attained levels of flexibility. Thus, co-workers flexibility arrangements are more likely to be accepted by individual's if they are able to attain their desired level of flexibility also.

Although i-deals tend to be brokered by valued employees, such as knowledge workers who are desirable in a competitive market, and therefore have greater power to negotiate their own employment conditions (e.g. Rousseau, 2001). More recent research highlighted that proactive employees even in standardized settings as the German civil service can negotiate flexibility terms beyond the programme policy and 'customized scheduling' (Hornung, Rousseau and Glaser, 2008:661). It is likely that negotiation between employers and employees across all employment levels is going to intensify because increasingly workers are looking to flexible working arrangements in order to meet their personal needs (e.g. Nadeem and Henry 2003; Hooker et al, 2007; PricewaterhouseCoopers 2010). Thus our findings have important implications for organizations. Organizations do not have to give global levels of flexibility to all staff. Employees want different levels of flexibility and there is scope for individuals and organizations to negotiate i-deals which benefit both parties. 
Penultimate version. If citing please refer instead to the published version in Human Resource Management Journal, 23(12), 2013

Allowing employees to reach their desired level of flexibility helps organizations attract and retain staff and in return allows organizations to meet operational demands.

Although organizations may introduce flexible working policies these are interpreted by line managers in different ways depending upon whether they are comfortable allowing people flexibility or to work from home. There are also implications for whom employees approach to negotiate i-deals with. Long term employees who have built up working relationships with managers previously, such as Sophie in this study, may approach them directly if they believe they would be more accommodating than team leaders. This has to be managed carefully as an individual who has their request for flexibility or homeworking turned down might be less accepting of the decision if another employee is granted their request (Dick, 2006). If there is inconsistency in a line manager's decisions, or across managers in the same department, it is hard to justify the business case for refusing a flexible working request especially when the computer system is available over an extended period. Also, if employees, as with the homeworkers in this study, can be closely monitored to check if they are working there is little risk to the organization to allow flexible working. Organizations may want to consider using the HR function to negotiate flexible i-deals with staff or to use them as a broker in the negotiations to promote fairness. There is also scope to trial an individual's flexibility request to allow adjustment from both the line manager and the individual.

\section{Study limitations and directions for future research}

The homeworkers who took part in this study were volunteers and appeared to have very strong positive feelings about homeworking. A small minority of homeworkers did appear reluctant to talk of any negative aspects of the homeworking scheme, specifically they did not want to be seen to 'moan' in case they jeopardised the scheme and this should be borne in mind when considering the results, although it does not invalidate them. Having said that, the 
Penultimate version. If citing please refer instead to the published version in Human Resource Management Journal, 23(12), 2013

qualitative approach adopted in this study has enabled a rich exploration of the psychological contracts of female clerical homeworkers within one organization and helps to capture, in a small way, 'the individualised employment experiences' of the psychological contracts of female clerical homeworkers thereby extending our understanding of the employer employer exchange relationship (Coyle-Shapiro and Parzefall, 2008:28). Although, the emphasis on one organization means we cannot assume their experiences and interpretations of the psychological contract can be used to make generalisations of contracts more widely.

Directions for future research could explore how supervisory staff mediate between company work-life balance initiatives and individual employees in other organizations and the consequences to the organization when some employees are unable to attain flexibility and others are. It would also be interesting to include a male perspective in future research given that men also desire work-life balance.

\section{Conclusion}

The findings from this study highlight the importance of temporal flexibility and fairness to the homeworkers in this study, and its importance within their psychological contact with the organization. Temporal flexibility was desired by the female homeworkers, regardless of whether they had children or not, in order to achieve a better work-life balance. In deciding to work at home the majority of homeworkers in this study either accepted a demotion or gave up a promotion to be able to work at home suggesting work was not the homeworkers main priority in life supporting research by Tietze and Nadin, (2011). This is an important finding as organizations who introduce work-life balance initiatives in order to attract and retain staff need to consider employees without children as well as those with dependent children. 
Penultimate version. If citing please refer instead to the published version in Human Resource Management Journal, 23(12), 2013

The findings from this study also suggest that the team leader, or immediate manager, represents the organisation for the homeworkers, acting as a gatekeeper in terms of whether the expectations of clerical staff are met. Certainly some expectations such as the level of temporal flexibility are at the discretion of the team leader. Although homeworkers were able to able to negotiate their own idiosyncratic deals with line managers in order to attain their desired levels of temporal flexibility, the issue remains ambiguous as homeworkers enjoy differing levels of flexibility. This finding has implications for any organization introducing work life balance initiatives as supervisory staff may not fully implement such schemes if they do not feel comfortable with them. Our findings suggest that employees perceive flexibility idiosyncratic deals of co-workers as fair as long as they achieve their own personal levels of flexibility. If the desired levels of temporal flexibility are not achieved then potentially employees may perceive a violation of their psychological contract which may negatively impact upon employer employee relations. 
Penultimate version. If citing please refer instead to the published version in Human Resource Management Journal, 23(12), 2013

References

Anand, S., Vidyarthi, P. R., Liden, R. C. Rousseau, D. M. (2010) 'Good citizens in poorquality relationships: Idiosyncratic deals as a substitute for relationship quality.' Academy of Management Journal, 53:5, 970-988

Avaya (2009) 'Flexible working 2009' [Online] [Accessed $8^{\text {th }}$ June 2010] Available from World Wide Web http://www.avaya.com/uk/emea/en-

us/resource/assets/premiumcontent/flexibleworking.pdf

Baruch,Y. (2001) 'The Status of Research on Teleworking and an Agenda for Future Research’. International Journal of Management Reviews, 3:2, 113-129

Bilton T, Bonnett K, Jones P, Stanworth, M and Webster A. (1996), Introductory Sociology, 3rd edition. London: Macmillan.

Chrobot-Mason D L (2003) ‘Keeping the promise: psychological contract violations for minority employees’. Journal of Managerial Psychology, 18:1, 22-45

Conway, N. and Briner, R. B. (2005) Understanding Psychological Contracts at Work: A Critical Evaluation of Theory and Research, Oxford:Oxford University Press 
Penultimate version. If citing please refer instead to the published version in Human Resource Management Journal, 23(12), 2013

Coyle-Shapiro A-M., Parzefall, M-R (2008) 'Psychological contracts’ in J Barling and C L Cooper (eds), The Sage Handbook of Organizational Behavior, Vol 1 Micro Perspectives, London: Sage

Crossan, G. and Burton, P. F. (1993) 'Teleworking Stereotypes: a Case Study’. Journal of Information Science, 19, 349-362.

Dick, P. (2006) 'The psychological contract and the transition from full to part-time police work'. Journal of Organizational Behavior, 27, 37-58.

Drew, E and Murtagh, E M (2005) 'Work/life balance: senior management champions or laggards?” Women in Management Review 20:3/4, 262-279

Fagan, C., Hegewisch, A. and Pillinger, J. (2006) 'Out of Time: Why Britain Needs a New Approach to Working Time Flexibility’. Research paper for the TUC. [Online] [Accessed $29^{\text {th }}$ December 2006] Available from World Wide Web: http:www.tuc.org.uk/extras/ outoftime.pdf

Feldman, M. S. and Pentland, B. T. (2003) 'Reconceptualizing organizational routines as a 
Penultimate version. If citing please refer instead to the published version in Human Resource Management Journal, 23(12), 2013

source of flexibility and change’. Administrative Science Quarterly, 48, 94-118.

Felstead, A. and Jewson, N. (2000) In Work, at Home: Towards an Understanding of Homeworking. London: Routledge.

Felstead, A., Jewson, N., Phizacklea, A., and Walters, S. (2002) 'The Option to Work at Home: Another Privilege for the Favoured Few?' New Technology, Work and Employment, $17: 3,204-223$

Felstead, A., Jewson, N. and Walters, S. (2003) Managerial control of employees working at home. British Journal of Industrial Relations, 41:2, 241-264.

Greenberg, J., Roberge, M. E., Ho, V. T., and Rousseau, D. (2004). ‘Fairness as an “i-deal”: Justice in under-the-table employment arrangements'. Research in Personnel and Human Resources Management, 22, 1-34.

Guest, D. E. (1998) 'Is the psychological contract worth taking seriously?’ Journal of Organizational Behavior, 19, 649-664. 
Penultimate version. If citing please refer instead to the published version in Human Resource Management Journal, 23(12), 2013

Guest, D. E. (2004) 'The psychology of the employment relationship: an analysis based on the psychological contract’ Applied Psychology: An International Review, 53:4, 541-555.

Guest, D. E. and Conway, N. (2002) 'Communicating the psychological contract: an employer perspective’ Human Resource Management Journal, 12:2, 22-38

Guzzo, R. A., Noonan, K. A. and Elron, E. (1994) 'Expatriate managers and the psychological contract’. Journal of Applied Psychology, 79:4, 617-626.

Haddon,L. and Silverstone, R. (1993) 'Homeworking in the 1990s - a view from the home'. A Report on the ESRC/PICT study of Homeworking and Information and Communication Technologies. [Online] [Accessed 3 May 2005] Available from World Wide Web: http:www.mot.chalmers.se/dept/tso/haddon/TELEREP.pdf

Herriot, P and Pemberton, C. (1995) New deals. Chichester:Wiley.

Herriot, P., Manning, W. E. G., and Kidd, J. M. (1997) 'The content of the Psychological 
Penultimate version. If citing please refer instead to the published version in Human Resource Management Journal, 23(12), 2013

contract’. British Journal of Management, 8, 151-162.

Higginbottom, K. (2006) 'How to earn less but feel richer’. The Independent, July $20^{\text {th }}$

Hilbrecht, M., Shaw, S. M., Johnson, L.C. and Andrey, J. (2008) 'I'm home for the kids': contradictory implications for work-life balance of homeworking mothers'. Gender, Work and Organization, 15:5, 454-476

Hogarth, T., Hasluck, C., Pierre, G., Winterbotham, M. and Vivian, D. (2000) 'Work-Life Balance 2000. Baseline Study of Work-Life Balance Practices in Great Britain’. Institute for Employment Research.

Holt, H., and Grainger, H (2005) 'Results of the second flexible working employee survey’. Office for National Statistics:Labour Market Trends

Hooker, H, Neathy, F., Casebourne, J and Munro, M. (2007) 'The third work-life balance survey: main findings’. Employment Relations Research series No. 58. DTI

Hornung, S. Rousseau, D. M. and Glaser, J. (2008) 'Creating flexible work arrangements 
Penultimate version. If citing please refer instead to the published version in Human Resource Management Journal, 23(12), 2013

through idiosyncratic deals’. Journal of applied Psychology, 93:3, 655-664.

Hornung, S. Rousseau, D. M. and Glaser, J. (2009) 'Why supervisors make idiosyncratic deals: antecedents and outcomes of i-deals from a managerial perspective, Journal of Managerial Psychology, 24:8, 738-764

Huws, U., Korte, W.B. and Robinson, S. (1990) Telework: towards the elusive office. Chichester:Wiley

Johnson, J (2004) 'Flexible working: changing the manager's role'. Management Decision, 42:6, 721-737.

Keating, M. (2006) 'A Chance to Step off the Treadmill'. The Guardian, 26 ${ }^{\text {th }}$ August.

King, N. (1994a) 'The qualitative research interview', in C. Cassell and G. Symon (eds), Qualitative Methods in Organizational Research: A Practical Guide. London:Sage.

King, N. (2004b) 'Using Templates in the Thematic Analysis of Text,' in C. Cassell and G. Symon (eds). Essential Guide to Qualitative Methods in Organizational Research. 
Penultimate version. If citing please refer instead to the published version in Human Resource Management Journal, 23(12), 2013

London:Sage.

Lai, L., Rousseau, D. M. and Chang, K. T.T (2009) 'Idiosyncratic deals: Coworkers as interested third parties.' Journal of Applied Psychology, 94:2,547-556.

McCarthy, A., Darcy, C. and Grady, G. (2010) 'Work-life balance policy and practice: Understanding line manager attitudes and behaviors'. Human Resource Management Review, 20, 158-167

Nadeem, S. and Hendry, C. (2003) 'Power dynamics in the long-term development of employee-friendly flexible working’. Women in Management Review, 18:1/2, 32-49.

Olson, M. H. and Primps, S. B. (1984) 'Working at Home with Computers: Work and Nonwork Issues’. Journal of Social Issues, 40(3), pp.97-112

Olson, M. H. (1988) ‘Organizational barriers to telework’, in W. B. Korte, S. Robinson, and W. J. Steinle (eds) Telework: Present Situation and Future Development of a New Form of Work Organization. Holland: Elsevier Science Publishers 
Penultimate version. If citing please refer instead to the published version in Human Resource Management Journal, 23(12), 2013

PricewaterhouseCooper (2010) Employees rate work-life balance over bonus [Online] [Accessed 8 June 2010] Available from World Wide Web:

http://www.ukmediacentre.pwc.com/News-Releases/Employees-rate-work-life-balance-overbonus-ea3.aspx

Purvis, L. J. and Cropley, M. (2003) 'The psychological contracts of national health service nurses’. Journal of Nursing Management, 11, 107-120.

Robinson, R., Kraatz, M. S. and Rousseau, D. M. (1994) 'Changing obligations and the psychological contract: a longitudinal study’. Academy of Management Journal, 37:1, 137152.

Robinson, S. L. and Morrison, E. W. (1995) 'Psychological contracts and the OCB: the effect of unfilled obligations on civic behavior'. Journal of Organizational Behavior, 16, 289-298.

Rousseau D M., (1989) ‘Psychological and Implied contracts in Organizations’. Employee Responsibilities and Rights Journal, 2(2), pp.121-139.

Rousseau, D. M. (1995) Psychological Contracts in Organizations: Understanding Written 
Penultimate version. If citing please refer instead to the published version in Human Resource Management Journal, 23(12), 2013

and Unwritten Agreements, Thousand Oaks, CA: Sage

Rousseau, D. M. (2001) ‘The idiosyncratic deal: flexibility versus fairness?’ Organizational Dynamics, 29:4, 260-273.

Rousseau, D. M (2005) I-Deals: Idiosyncratic Deals Employees Bargain for Themselves. New York:Sharpe

Rousseau, D. M., Ho, V. T. and Greenberg, J. 'I-deals: Idiosyncratic terms in employment relationships. Academy of Management Review, 31:4, 977-994

Scandura, T. A. and Lankau, M. J. (1997)'Relationships of gender, family responsibility and flexible work hours to organizational commitment and job satisfaction'. Journal of Organizational Behavior, 18, 377-391.

Sullivan, C. and Lewis, S. (2001) 'Home-based telework, gender, and the synchronization of work and family: perspectives of homeworkers and their co-residents'. Gender, Work and Organization, 8:2, 123-145. 
Penultimate version. If citing please refer instead to the published version in Human Resource Management Journal, 23(12), 2013

Tietze, S. and Musson, G. (2002) ‘When ‘work’ meets ‘home’: temporal flexibility as lived experience'. Time and Society, 11:2/3, 315-334.

Tietze, S. and Musson, G. (2005) 'Recasting the home-work relationship: a case of mutual adjustment?’ Organization Studies, 26:9, 1331-1352.

Tietze, S. and Nadin, S. (2011) 'The psychological contract and the transition from officebased to home-based work’. Human Resource Management Journal, 21(3), 318-334.

Tekleab, A. G. and Taylor, S. (2003) ‘Aren't There Two Parties In An Employment Relationship? Antecedents and Consequences of Organization-Employee Agreement on Contract Obligations and Violations'. Journal of Organizational Behavior, 24, pp.585-608.

Tom, E. (2004) Find the Balance: Essential Steps to Fulfilment in your Work and Life. London:BBC Books.

Tremblay,D. G. (2002) 'Balancing Work and Family with Telework? Organizational Issues and Challenges for Women and Managers'. Women in Management Review, 17(3/4), pp. 157170. 
Penultimate version. If citing please refer instead to the published version in Human Resource Management Journal, 23(12), 2013 
Penultimate version. If citing please refer instead to the published version in Human Resource Management Journal, 23(12), 2013

Table 1

\begin{tabular}{|c|c|c|c|c|}
\hline Name & Grade & $\begin{array}{l}\text { Length of time } \\
\text { worked from } \\
\text { home (in months) }\end{array}$ & $\begin{array}{l}\text { Supervisor/Team } \\
\text { Leader }\end{array}$ & Children \\
\hline \multicolumn{5}{|c|}{ Supervisory staff } \\
\hline Peter & Manager & N/A & & \\
\hline Rebecca & Manager & $\mathrm{N} / \mathrm{A}$ & & \\
\hline Jennifer & Teamleader & N/A & & \\
\hline Mary & Teamleader & N/A & & \\
\hline Robert & Teamleader & N/A & & \\
\hline Debbie & Teamleader & $\mathrm{N} / \mathrm{A}$ & & \\
\hline Sam & Supervisor & 24 & & \\
\hline Heather & Supervisor & N/A & & \\
\hline \multicolumn{5}{|c|}{ Homeworkers } \\
\hline Amy & & 10 & Sam/Jennifer & No \\
\hline Hannah & & 12 & Sam/Jennifer & Yes \\
\hline Katherine & & 10 & Sam/Jennifer & No \\
\hline Laura & & 24 & Sam/Jennifer & No \\
\hline Louise & & 48 & Sam/Mathew & Yes \\
\hline Sophie & & 48 & $\begin{array}{l}\text { Guy or Sam/Mathew } \\
\text { tends to avoid Jennifer }\end{array}$ & No \\
\hline Amanda & & 22 & Debbie (Team leader) & Yes \\
\hline Gail & & 20 & Debbie (Team leader) & Yes \\
\hline Nicola & & 30 & Debbie (Team leader) & Yes \\
\hline Charlotte & & 36 & Robert (Team leader) & Yes \\
\hline Gillian & & 36 & Robert (Team leader) & No \\
\hline Emily & & 18 & Robert (Team leader) & Yes (not dependent) \\
\hline Erin & & 18 & Rebecca (Manager) & Yes \\
\hline
\end{tabular}


Penultimate version. If citing please refer instead to the published version in Human Resource Management Journal, 23(12), 2013

Table 2

\begin{tabular}{|l|c|}
\hline Expectation & Homeworkers (\%) \\
\hline $\begin{array}{l}\text { Temporal flexibility/ Time off to meet personal } \\
\text { or family needs }\end{array}$ & $13(100)$ \\
\hline Fairness & $13(100)$ \\
\hline Training & $10(77)$ \\
\hline Job Security & $10(77)$ \\
\hline Support & $8(61)$ \\
\hline Communication & $5(38)$ \\
\hline
\end{tabular}

